\title{
Red Imported Fire Ants Reduce Invertebrate Abundance, Richness, and Diversity in Gopher Tortoise Burrows
}

\author{
Deborah M. Epperson ${ }^{1}$, Craig R. Allen ${ }^{2, *}$ and Katharine F. E. Hogan ${ }^{2, *}$ (D) \\ 1 U.S. Geological Survey—Wetland and Aquatic Research Center, Gainesville, FL 32653, USA; \\ depperson@usgs.gov \\ 2 Center for Resilience in Agricultural Working Landscapes, School of Natural Resources, University of Nebraska, \\ Lincoln, NE 68583-0961, USA \\ * Correspondence: callen3@unl.edu (C.R.A.); katharine.hogan@huskers.unl.edu (K.F.E.H.); \\ Tel.: +1-(308)-258-2829 (K.F.E.H.)
}

check for

updates

Citation: Epperson, D.M.; Allen, C.R.; Hogan, K.F.E. Red Imported Fire Ants Reduce Invertebrate Abundance,

Richness, and Diversity in Gopher Tortoise Burrows. Diversity 2021, 13, 7. https://doi.org/10.3390/d13010007

Received: 30 November 2020 Accepted: 26 December 2020 Published: 29 December 2020

Publisher's Note: MDPI stays neutral with regard to jurisdictional claims in published maps and institutional affiliations.

Copyright: (C) 2020 by the authors. Licensee MDPI, Basel, Switzerland. This article is an open access article distributed under the terms and conditions of the Creative Commons Attribution (CC BY) license (https: / / creativecommons.org/ licenses/by/4.0/).

\begin{abstract}
Gopher Tortoise (Gopherus polyphemus) burrows support diverse commensal invertebrate communities that may be of special conservation interest. We investigated the impact of red imported fire ants (Solenopsis invicta) on the invertebrate burrow community at 10 study sites in southern Mississippi, sampling burrows (1998-2000) before and after bait treatments to reduce fire ant populations. We sampled invertebrates using an ant bait attractant for ants and burrow vacuums for the broader invertebrate community and calculated fire ant abundance, invertebrate abundance, species richness, and species diversity. Fire ant abundance in gopher tortoise burrows was reduced by $>98 \%$ in treated sites. There was a positive treatment effect on invertebrate abundance, diversity, and species richness from burrow vacuum sampling which was not observed in ant sampling from burrow baits. Management of fire ants around burrows may benefit both threatened gopher tortoises by reducing potential fire ant predation on hatchlings, as well as the diverse burrow invertebrate community. Fire-ant management may also benefit other species utilizing tortoise burrows, such as the endangered Dusky Gopher Frog and Schaus swallowtail butterfly. This has implications for more effective biodiversity conservation via targeted control of the invasive fire ant at gopher tortoise burrows.
\end{abstract}

Keywords: invasion ecology; invasive species; red imported fire ant; commensalism; gopher tortoise; diversity; conservation; burrow commensal

\section{Introduction}

Invertebrates are an integral component of most food webs either directly as predators, prey, or indirectly through nutrient cycling [1]. The introduction of non-native species can decimate invertebrate communities resulting in a loss of native species diversity and the potential loss of ecosystem processes [2]. While data are limited on most invertebrate species, some studies report that two-thirds of invertebrate species have declined by $45 \%$ in mean abundance [3], with regional studies sometimes reporting much higher losses [4]. Effective use of limited conservation resources may lie in conserving biodiverse "hotspots" that account for a small percentage of the earth's surface [5-7]. Sometimes, these hotspots are created by the presence of keystone or ecosystem engineer species, such as the gopher tortoise (Gopherus polyphemus) of the southeastern United States [8].

Gopher tortoises excavate burrows in uplands on well-drained soils that provide habitat for more than 360 species [8-10]. Gopher tortoise burrows vary in size, but may extend up to 10 meters in length [8] and can persist for decades [11], enabling an invertebrate commensal community time to develop and stabilize [12]. No other North American reptile digs such a large, extensive, and relatively stable burrow [12], which makes the associated community of particular interest. In addition to their longevity in upland habitats, these burrows provide a stable thermal refugia for tortoises and other species [13]. 
A review of all known literature on the fauna of gopher tortoise burrows listed 60 vertebrate and 302 invertebrate species that use gopher tortoise burrows [10]. In this review, the criteria for commensalism were that "taxa that had at least 10 records of burrow use, or for which anecdotal reports are especially numerous." [10]. Based on these criteria, the invertebrate communities found in burrows contain dozens of commensal species, plus dozens more listed as "frequent users" that may also be commensal [10].

Populations of gopher tortoises in southern Mississippi have lower genetic diversity than populations from the eastern part of their range [14] and may be more vulnerable to disturbances and of higher conservation interest [15]. Additionally, research in Mississippi [16] supports evidence of gopher tortoise burrows as biodiverse communities with distinct commensal elements. While most early tortoise burrow community sampling was in Florida, Mississippi gopher tortoise habitats are different in vegetation and soil characteristics [16]. Thirty-seven species in 11 families and 5 orders of insects, and one species of tick were collected from burrows in Mississippi, many of which had not been recorded in earlier research [16]. The presence of diverse, but different invertebrate communities utilizing gopher tortoise burrows in different vegetation and soil conditions suggests that tortoises actively create desirable habitat for many species across invertebrate taxa. This supports previous evidence that these invertebrate communities are commensal to some degree [10] and highlights the importance of conserving tortoise populations in this region [15].

Lago (1991) was the first to record red imported fire ants (Solenopsis invicta Buren) as present in tortoise burrows, attacking a beetle at a burrow entrance [16]. The fire ant arrived at the Port of Mobile, Alabama from South America in the 1930s and has since spread across the United States [17] as far west as California [18]. Fire ants are aggressive, generalist predators that consume a variety of prey, including many other invertebrate species and gopher tortoise hatchlings [2,19]. Fire ants have reduced native ant diversity [20,21] in the Southeastern United States, as well as affected native invertebrate communities and associated ecosystem processes $[2,22,23]$. Once established, fire ants are extremely difficult to eradicate [24], and along with other invasive species are one of the greatest threats to native biodiversity and ecosystems $[25,26]$.

In providing a unique microhabitat for many invertebrate species, gopher tortoise burrows also provide foraging opportunities for other species. An abundance of prey, soil disturbance around the burrow (called an "apron"), and the location of gopher tortoise burrows in sunny areas may provide suitable foraging and nesting habitat for fire ants [27]. One study found that $50 \%$ of all burrow aprons sampled in Mississippi had active fire ant mounds present [28], while another study found them present at 33\% of burrows [29].

Although the impacts of fire ants on native biodiversity are generally well documented [22,30-32], the impacts of fire ants on invertebrates within gopher tortoise burrows are not. In this study, we assessed the impact of fire ants on commensal invertebrate communities within gopher tortoise burrows by manipulating fire ant densities on large replicated plots. Using two methods (burrow baits and vacuuming), we determined the relative abundance of fire ants and other burrow invertebrates as well as species richness and species diversity in the burrow system before and after treatments to reduce fire ant populations. We conclude by briefly discussing implications for conservation and fire ant control.

\section{Materials and Methods}

The study was conducted at Camp Shelby Joint Forces Training Center (CSJFTC) in southern Mississippi, USA, which is the nation's largest Army National Guard training site (Figure 1). It covers approximately 54,471 hectares, of which 47,561 hectares are U.S. National Forest land. 


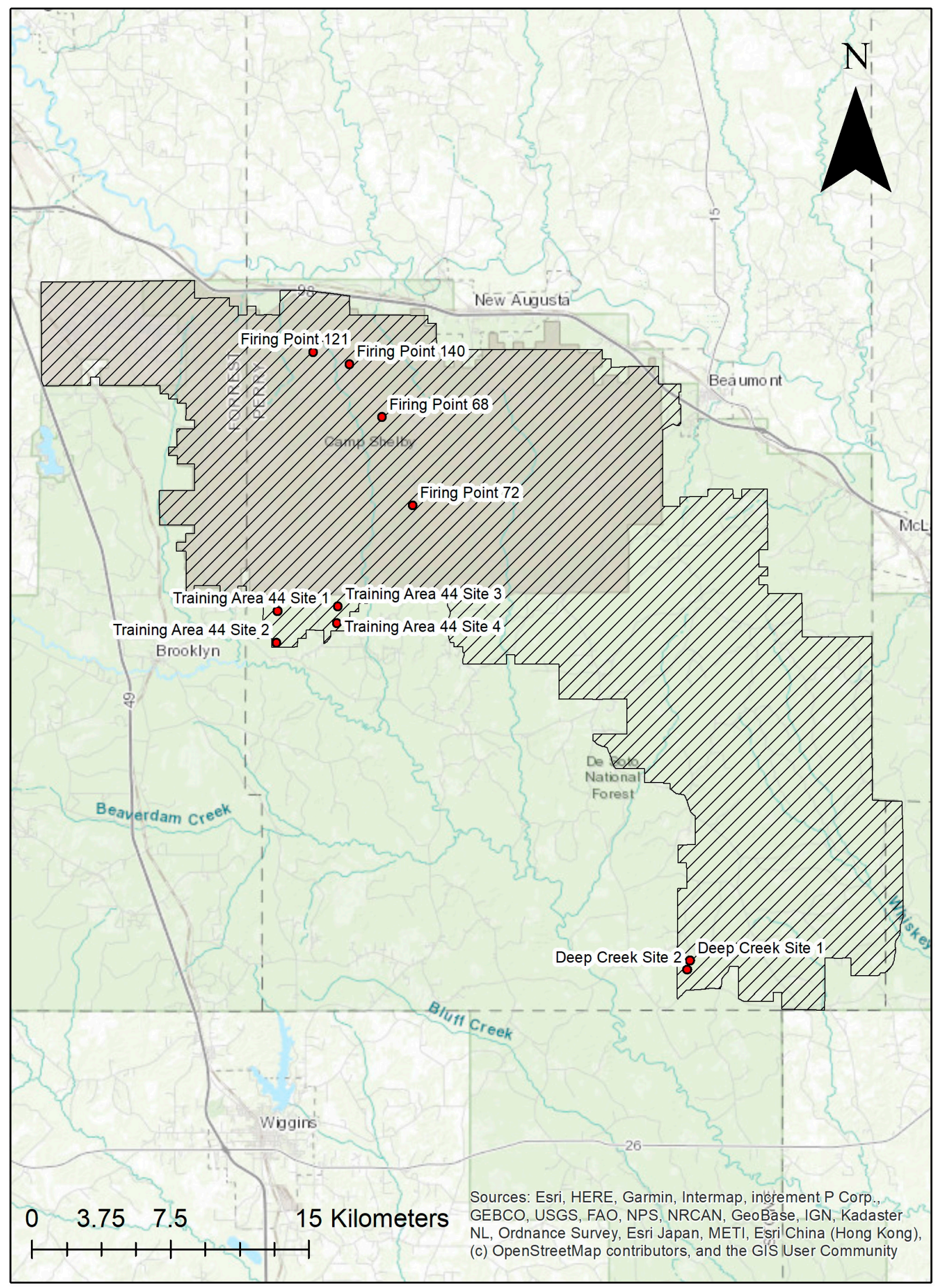

Figure 1. Map of Camp Shelby Joint Forces Training Center (CSJFTC). Study sites are labelled points. 
In the spring of 1997, we selected ten sites (20-40 ha each) within CSJFTC for this study (Table A1, Appendix A). The ten sites were paired based on habitat similarities and gopher tortoise densities which allowed us to collect data from 10 burrows within each site, for a total of 100 burrows sampled multiple times. Four of the sites ( 2 pairs) are National Guard firing points (locations where heavy artillery shoots onto firing ranges) that are mowed and are considered ruderal habitat. Since they were paired by habitat, two of these sites (Firing Points 140 and 68) were located $3.36 \mathrm{~km}$ apart, and the remaining two (Firing Points 121 and 72) were $9.88 \mathrm{~km}$ apart. Three of the four firing points are surrounded by longleaf pine (Pinus palustris), and the fourth firing point is surrounded by slash pine (Pinus elliottii). Four sites (2 pairs) were in a gopher tortoise refuge (Training Area 44 or T-44, Sites 1-4), with pairs being contiguous (Sites 1-2, and 3-4). These sites are predominantly longleaf pine with some bluestem (Schizachyrium spp.) dominated groundcover. The remaining sites (Deep Creek 1 and 2) were also contiguous, located in a longleaf plantation (planted 1986) and an adjacent, more mature longleaf stand.

The National Guard mows the firing points annually between November and March, and the U.S. Forest Service manages the forested study sites and forested areas surrounding the firing points. Prescribed fire is the preferred management tool. However, fire intervals and season of burn are different from the natural burn regime of the area. The military use of these sites also varies, but firing points are the most heavily impacted by military use, including tank maneuvers and heavy artillery firing. The sites in T-44 have activity restricted to foot traffic, and some limited firing on the firing points contained within T-44. The two remaining sites have no military use.

Prior to data collection, we treated one randomly chosen site from each pair of sites with LOGIC ${ }^{\circledR}$ fire ant bait in spring 1998, spring and fall of 1999, and the spring of 2000. We completed broadcast applications of the bait by both manual hand spreaders and mechanized ground equipment (4-wheeler and tractor) at the rate of approximately $1.67 \mathrm{~kg}$ per hectare.

To evaluate use of the burrows by ants, we placed a bait attractant approximately 1 meter into the burrow of ten random adult gopher tortoise burrows at every site. The bait attractant apparatus used to sample burrows was a cotton ball infused with MultiSpecies Ant Attractant (MSAA; [33]) within a small (30 mL) perforated plastic condiment container. The MSAA is a mixture of de-ionized water, confectionary sugar, and sodium hydroxide. The container was attached to a meter stick with monofilament line and placed inside the burrow. After one hour, we removed the baits, placed ant samples into Ziploc bags and froze them until they could be transported to the United States Department of Agriculture-Agricultural Research Service (USDA-ARS) laboratory in Gainesville, FL, USA for identification. We sorted all samples and identified ants to family, and to genus and species when possible. We repeated this sampling in the spring and fall of 1998, 1999, and 2000 at the same 10 burrows at each site. Data generated for this study are available within the Supplementary Materials.

To evaluate the invertebrate commensal burrow community, we vacuumed the same ten randomly chosen adult burrows at each site with a D-Vac (John W. Hock Co., Gainesville, FL, USA). The vacuum apparatus was placed as far down the burrow as possible (2-5 m) and then the burrow was suctioned as the vacuum was withdrawn slowly from the burrow. We placed samples in Ziploc bags and froze them until they could be transported to the USDAARS-Plant Protection and Quarantine laboratory in Gulfport, MS, USA for identification. We sorted all samples and identified invertebrates to family, and to genus and species when possible. We sampled using the burrow vacuum in the spring and fall of 1998, 1999, and 2000 at the same 10 burrows at each site.

To characterize the ant community in tortoise burrows based on the burrow baiting with MSAA, we calculated fire ant abundance, species richness (excluding fire ants), and species diversity (excluding fire ants) at each site for each of the six sampling periods (1 prior to the first treatment, 5 post-treatment). We averaged data from all ten burrows to derive a value for each site. We determined species richness, and calculated Shannon's 
Diversity $\mathrm{H}^{\prime}$ [34]. We compared the pre-treatment sampling period between treated and untreated sites using a randomized block design analysis of variance (ANOVA). Posttreatment data were compared using a repeated measures randomized block analysis of variance. Due to missing data for one time period for two sites, we compared post-treatment fire ant abundance, species richness, and species diversity data using the PROC MIXED function (SAS Institute Inc., Cary, NC, USA, 1999). We tested all data for normality using the Shapiro-Wilk test. All data were normally distributed. We considered a probability level of 0.05 as significant.

To characterize the broader invertebrate communities in tortoise burrows from the vacuuming, we repeated the same analyses by determining fire ant abundance, invertebrate abundance (excluding fire ants), species richness (excluding fire ants), and species diversity (excluding fire ants) at each site for each of the six sampling periods (1 pre-treatment, 5 posttreatment). We compared the pre-treatment sampling period between treated and untreated sites using a randomized block design analysis of variance (ANOVA) (SAS Institute, Inc., 1999), and compared post-treatment data using a repeated measures randomized block ANOVA. We determined species richness and calculated diversity using Shannon Diversity $\mathrm{H}^{\prime}$ [34]. We tested all data for normality using the Shapiro-Wilk test. All data were normally distributed. We considered a probability level of 0.05 as significant.

\section{Results}

The repeated treatments with LOGIC ${ }^{\circledR}$ significantly reduced fire ant abundance in our study sites [22] and this was confirmed by the burrow baiting and burrow vacuum samples which had a $98.8 \%$ and $99.9 \%$ reduction in fire ant abundance, respectively. The invertebrate community in tortoise burrows included 17 invertebrates positively identified to species from 13 genera and 8 families. In many cases, invertebrates could only be identified to class, genus or family resulting in species collected from four classes and ten orders (Table 1). Insects from eight orders were collected, some found only on treated sites including Lepidoptera, Blattaria, and "Hemiptera" (Genus A).

Table 1. Invertebrates collected from all sites using a burrow vacuum for six sampling periods (1 pre-treatment, 5 post-treatment). If possible, specimens were identified to genus and species. "Treated" refers to species found only on sites treated to reduce fire ant populations, "untreated" refers to species found only on untreated sites, and "both" refers to species found on both treated and untreated sites. Species annotated with an "**" were considered "commensal" [10].

\begin{tabular}{|c|c|c|c|c|c|}
\hline Class & Order & Family & Genus & Species & Treatment \\
\hline CHILOPODA & & & & & Both \\
\hline DIPOPLODA & & & & & Both \\
\hline \multirow[t]{8}{*}{ ARACHNIDA } & Araneae & Agelenidae & Agelenopsis & naevia & Treated \\
\hline & & & Agelenopsis & & Both \\
\hline & & & Coras & & Untreated \\
\hline & & & Neoscona & . & Untreated \\
\hline & & & Tegeraria & domestica & Treated \\
\hline & & Araneidae & Araneus & . & Treated \\
\hline & & & Genus A & & Untreated \\
\hline & & & Argiope & aurantia & Treated \\
\hline \multirow[t]{9}{*}{ INSECTA } & & Gnaphosidae & Gnaphosa & . & Both \\
\hline & & Hahniidae & Genus A & & Untreated \\
\hline & & Linphiidae & Genus A & & Treated \\
\hline & & Lycosidae & $L y \cos a$ & helluo & Both \\
\hline & & & $L y \cos a$ & avida & Treated \\
\hline & & & $L y \cos a$ & rabida & Treated \\
\hline & & & Lycosa & . & Untreated \\
\hline & & & Schizocosa & & Untreated \\
\hline & & & Sossipus & . & Both \\
\hline
\end{tabular}


Table 1. Cont.

\begin{tabular}{|c|c|c|c|c|c|}
\hline Class & Order & Family & Genus & Species & Treatment \\
\hline & & Mimetidae & Mimetus & & Treated \\
\hline & & Philodromidae & Apollophanes & & Treated \\
\hline & & Salticidae & Evarcha & & Untreated \\
\hline & & & Phidippus & & Treated \\
\hline & Opiliones & Phalangidae & Genus A & & Treated \\
\hline & Blattaria & Blatellidae & Genus A & & Treated \\
\hline & Coleoptera & Scarabaeidae & Aphodius & & Both \\
\hline & & Staphylinidae & Genus A & & Both \\
\hline & & Carabidae & Agonum & & Treated \\
\hline & & & Clivinia & & Untreated \\
\hline & & Curclionidae & Pantomorus & cervinus & Untreated \\
\hline & & Nitidulidae & Genus A & & Untreated \\
\hline & & Elateridae & Genus A & & Treated \\
\hline & Diptera & Anthomyidae & Eutrichota & gopheri * & Both \\
\hline & & Chironomidae & Genus A & & Untreated \\
\hline & & Culicidae & Genus A & & Both \\
\hline & & Dolichopodidae & Hercostoma & & Both \\
\hline & & & Hercostoma & & Both \\
\hline & & Sphaeroceridae & Genus A & & Both \\
\hline \multirow[t]{21}{*}{ INSECTA } & Hemiptera & Lygaeidae & Genus A & & Untreated \\
\hline & & Miridae & Genus A & & Treated \\
\hline & & Pentatomidae & Thylantea & calceata & Untreated \\
\hline & & Cicadellidae & Genus A & & Both \\
\hline & & & Genus B & & Treated \\
\hline & Hymenoptera & Braconidae & Genus A & & Untreated \\
\hline & & Formicidae & Aphenogaster & carolinense & Treated \\
\hline & & & Aphenogaster & lamellidans & Both \\
\hline & & & Aphenogaster & & Both \\
\hline & & & Brachymyrmex & depilis & Treated \\
\hline & & & Cyphomyrmex & rimosus & Both \\
\hline & & & Dorymyrmex & bureni & Both \\
\hline & & & Dorymyrmex & medeis & Both \\
\hline & & & Paratrechina & & Both \\
\hline & & & Solenopsis & invicta & Both \\
\hline & & Halictidae & Genus A & & Treated \\
\hline & & Mutillidae & Dasymutilla & & $\begin{array}{c}\text { Treated } \\
\text { Both }\end{array}$ \\
\hline & Lepidoptera & & & & Treated \\
\hline & Orthoptera & Gryllacridae & Ceutophilis & divergens* & Both \\
\hline & & Gryllidae & Gryllus & & Treated \\
\hline & & Tettigoniidae & & & Both \\
\hline
\end{tabular}

\subsection{Burrow Baits}

There were few ants present in the burrows besides fire ants and treating for fire ants did not increase overall ant abundance, richness, or diversity in the burrows. Pretreatment fire ant abundance was not significantly different between sites $(\mathrm{F}=3.29, \mathrm{df}=4, \mathrm{P}=0.144)$. Repeated LOGIC ${ }^{\circledR}$ applications significantly reduced fire ant abundance at treated sites (Figure 2, $\mathrm{F}_{1,8}=24.78, \mathrm{P}=0.001$ ). Pre-treatment ant species diversity (excluding fire ants) was 0 for both treated and untreated sites. Pre-treatment species richness also was low and was not significantly different between treated and untreated sites (Figure 3, F = 1.0, $\mathrm{df}=4, \mathrm{P}=0.374)$. After reducing fire ant populations, there were no significant differences in ant species richness (Figure $3, \mathrm{~F}_{1,8}=0.01, \mathrm{P}=0.935$ ) or ant species diversity (Figure 4, $\mathrm{F}_{1,8}=0.14, \mathrm{P}=0.722$ ) between treated and untreated sites. We collected thirteen species of ants (including fire ants) using burrow baits (Table 2). Of these, two species were unique to treated sites, and four species unique to untreated sites. 

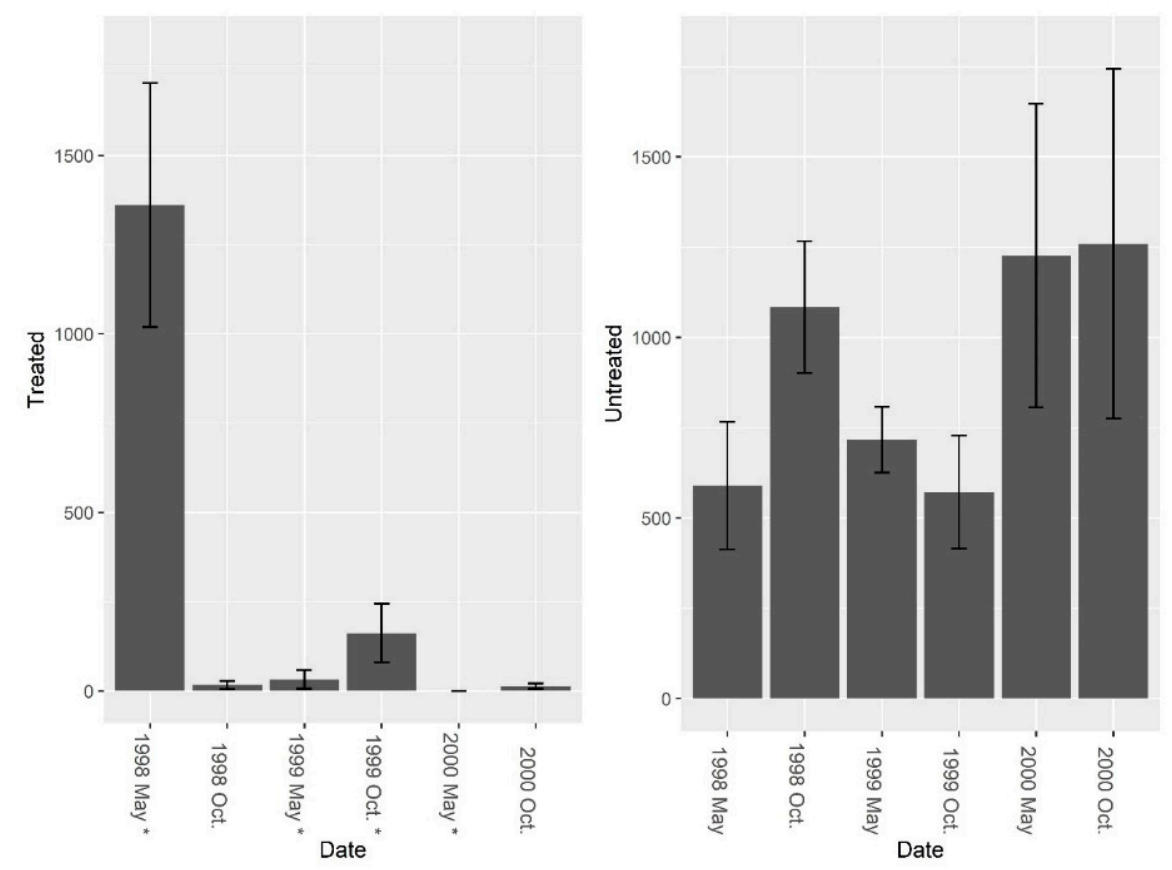

Figure 2. Mean $( \pm 1 \mathrm{SE})$ fire ant abundance from burrow baits at five pairs of treated and untreated study sites at CSJFTC, 1998-2000. Fire ant abundance declined 98.8\% in treated sites, and increased $53.2 \%$ in untreated sites. Post-treatment data were compared using a repeated measures randomized block ANOVA, and repeated LOGIC ${ }^{\circledR}$ applications significantly reduced fire ant abundance at treated sites $\left(F_{1,8}=24.78, P=0.001\right)$. Asterisks on the $x$-axis indicate when treatments occurred.
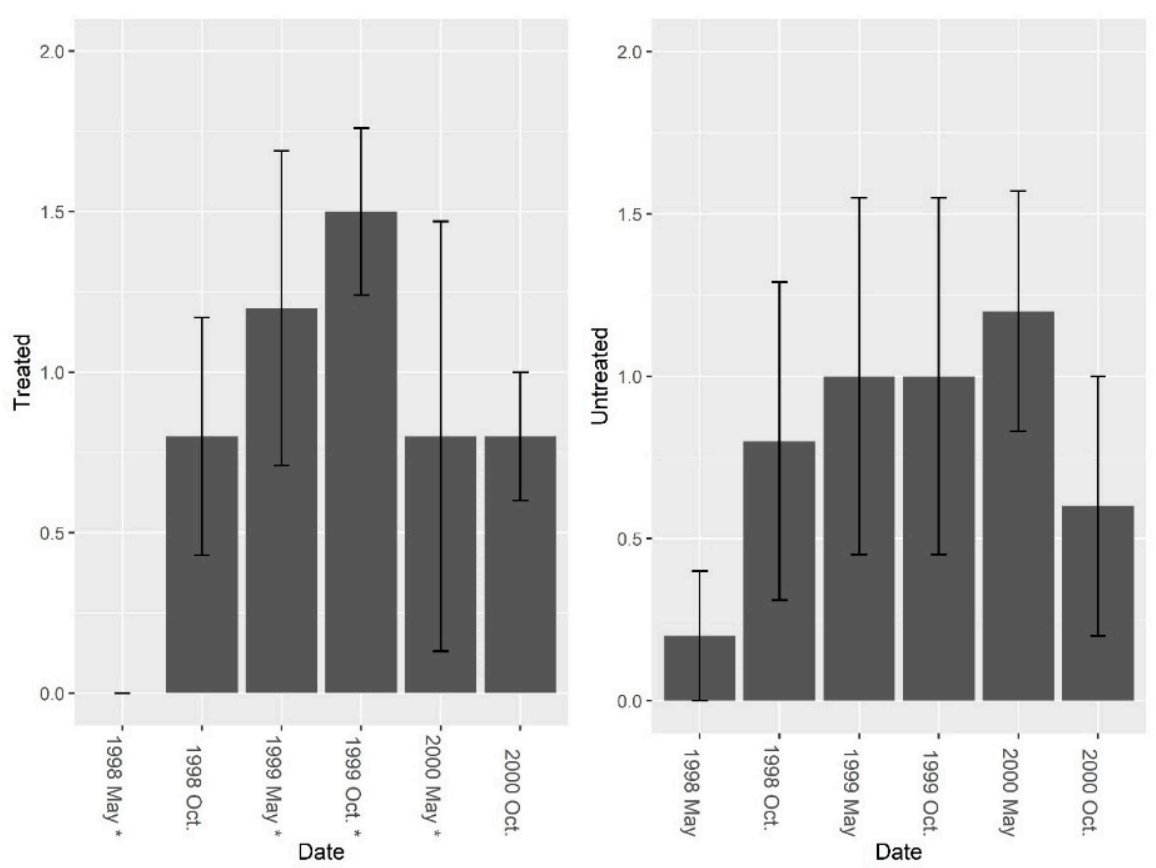

Figure 3. Mean $( \pm 1 \mathrm{SE})$ ant (excluding fire ant) species richness collected from burrow baits at five pairs of treated and untreated study sites at CSJFTC, 1998-2000. There were no significant differences between study sites from a randomized block design ANOVA $(\mathrm{F}=1.0, \mathrm{df}=4, \mathrm{P}=0.374)$. Asterisks on the $x$-axis indicate when treatments occurred. 

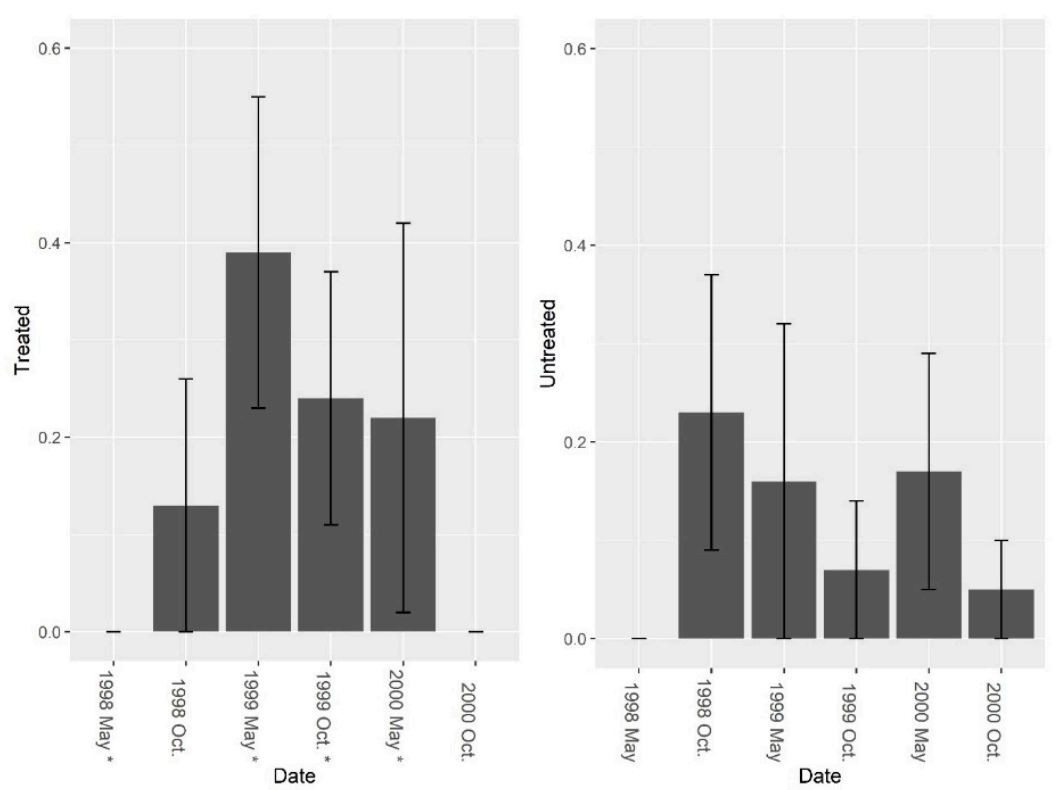

Figure 4. Mean ( $\pm 1 \mathrm{SE})$ ant (excluding fire ant) species Shannon diversity indices collected from burrow bait at five pairs of treated and untreated study sites at CSJFTC, 1998-2000. There were no significant differences between study sites from a randomized block design ANOVA $\left(\mathrm{F}_{1,8}=0.14\right.$, $\mathrm{P}=0.722)$. Asterisks on the $\mathrm{x}$-axis indicate when treatments occurred.

Table 2. Ant species (Hymenoptera: Formicidae) found using burrow baits at all study sites on CSJFTC, 1998-2000. "Treated" refers to species found only on sites treated to reduce fire ant populations, "untreated" refers to species found only on untreated sites, and "both" refers to species found on both treated and untreated sites.

\begin{tabular}{cc}
\hline Scientific Name & Treatment \\
\hline Aphenogaster near rudis & both \\
Brachymyrmex depilis & treated \\
Dorymyrmex bureni & both \\
Paratrechina concinna & untreated \\
Paratrechina longicornis & both \\
Paratrechina phantasma & untreated \\
Pheidole dentata & treated \\
Pheidole dentigula & untreated \\
Pheidole floridana & both \\
Pheidole metallescens & both \\
Pheidole moerens & both \\
Solenopsis sp. & untreated \\
Solenopsis invicta & both \\
\hline
\end{tabular}

\subsection{Burrow Vacuums}

Data from the burrow vacuums revealed significant increases in overall invertebrate abundance, richness, and diversity post-treatment. Pre-treatment fire ant abundance was not significantly different between sites (Figure $5, \mathrm{~F}=2.01$, $\mathrm{df}=4, \mathrm{P}=0.229$ ). Overall, treatment effects were significant (Figure 5, $\mathrm{F}_{1,7}=7.37, \mathrm{P}=0.030$ ), and fire ant abundance in burrows was significantly reduced by repeated LOGIC ${ }^{\circledR}$ applications. Pre-treatment abundance of burrow invertebrates (excluding fire ants) was significantly different between sites (Figure 6, $\mathrm{F}=14.14, \mathrm{df}=4, \mathrm{P}=0.019$ ), and while treatment effects varied over time periods, an overall nearly significant treatment effect was present (Figure 6; $\mathrm{F}_{1,7}=4.01$, $\mathrm{P}=0.085$ ). Invertebrate abundance was greater on treated sites and did not change from pre-treatment to post-treatment. Species richness (excluding fire ants) was not significantly different between sites pre-treatment (Figure 7, $\mathrm{F}=3.37, \mathrm{df}=4, \mathrm{P}=0.140$ ); however, richness 
was greater on treated sites post-treatment (Figure $7 ; \mathrm{F}_{1,7}=24.73, \mathrm{P}=0.002$ ). Pre-treatment species diversity (excluding fire ants) was not significantly different between sites (Figure 8 , $\mathrm{F}=0.44, \mathrm{df}=4, \mathrm{P}=0.543$ ). Post-treatment, a significant treatment effect was observed (Figure $8: F_{1,7}=9.31, P=0.019$ ) in species diversity between treated and untreated sites.
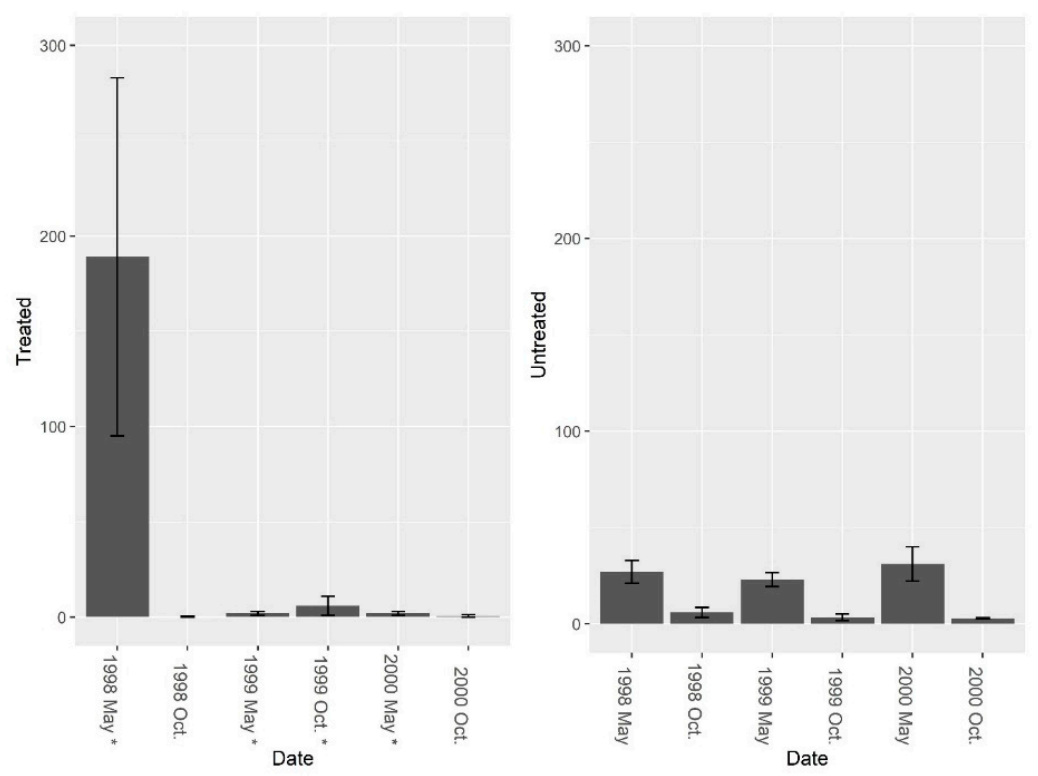

Figure 5. Mean ( $\pm 1 \mathrm{SE}$ ) fire ant abundance collected from burrow vacuuming at five pairs of treated and untreated study sites at CSJFTC, 1998-2000. Fire ant abundance declined 99.9\% in treated sites, and decreased $55.6 \%$ in untreated sites Pre-treatment fire ant abundance was not significantly different between study sites $(\mathrm{F}=2.01, \mathrm{df}=4, \mathrm{P}=0.229)$. Post-treatment data were compared using a repeated measures randomized block ANOVA, and repeated LOGIC ${ }^{\circledR}$ applications significantly reduced fire ant abundance $\left(\mathrm{F}_{1,7}=7.37, \mathrm{P}=0.030\right)$. Asterisks on the $\mathrm{x}$-axis indicate when treatments occurred.
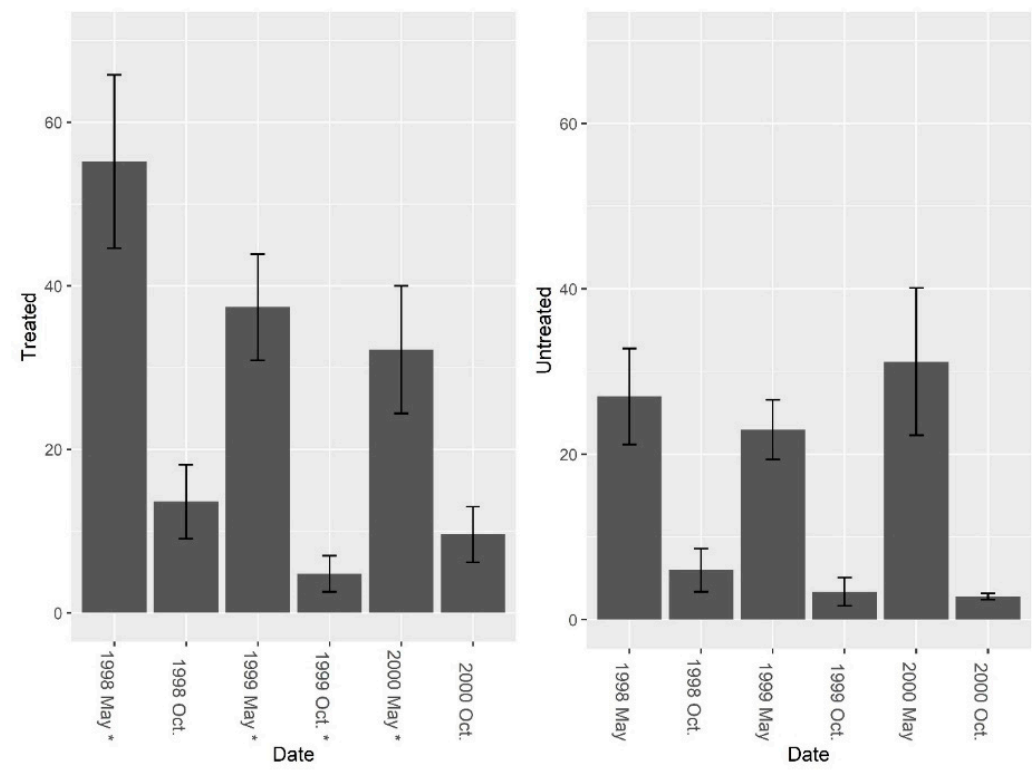

Figure 6. Mean ( $\pm 1 \mathrm{SE}$ ) invertebrate abundance (excluding fire ants) collected from burrow vacuuming at five pairs of treated and untreated study sites at CSJFTC, 1998-2000. Pre-treatment abundance of burrow invertebrates (excluding fire ants) was significantly different between sites $(\mathrm{F}=14.14, \mathrm{df}=4$, $\mathrm{P}=0.019)$, and a nearly significant treatment effect was present $\left(\mathrm{F}_{1,7}=4.01, \mathrm{P}=0.085\right)$. Asterisks on the $x$-axis indicate when treatments occurred. 

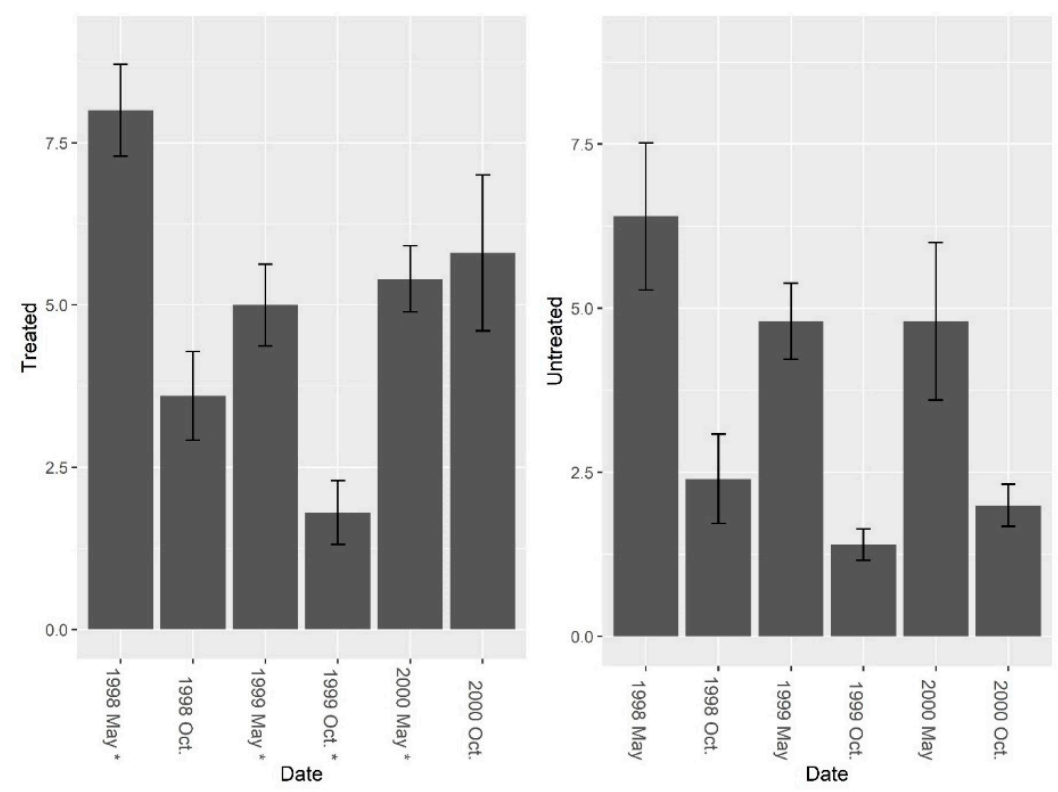

Figure 7. Mean ( $\pm 1 \mathrm{SE}$ ) species richness (excluding fire ants) collected from burrow vacuuming at five pairs of treated and untreated study sites at CSJFTC, 1998-2000. Species richness (excluding fire ants) was not significantly different between treated and untreated sites pre-treatment $(\mathrm{F}=3.37$, $\mathrm{df}=4, \mathrm{P}=0.140)$, but species richness was greater on treated sites post-treatment $\left(\mathrm{F}_{1,7}=24.73\right.$, $\mathrm{P}=0.002$ ). Asterisks on the $\mathrm{x}$-axis indicate when treatments occurred.
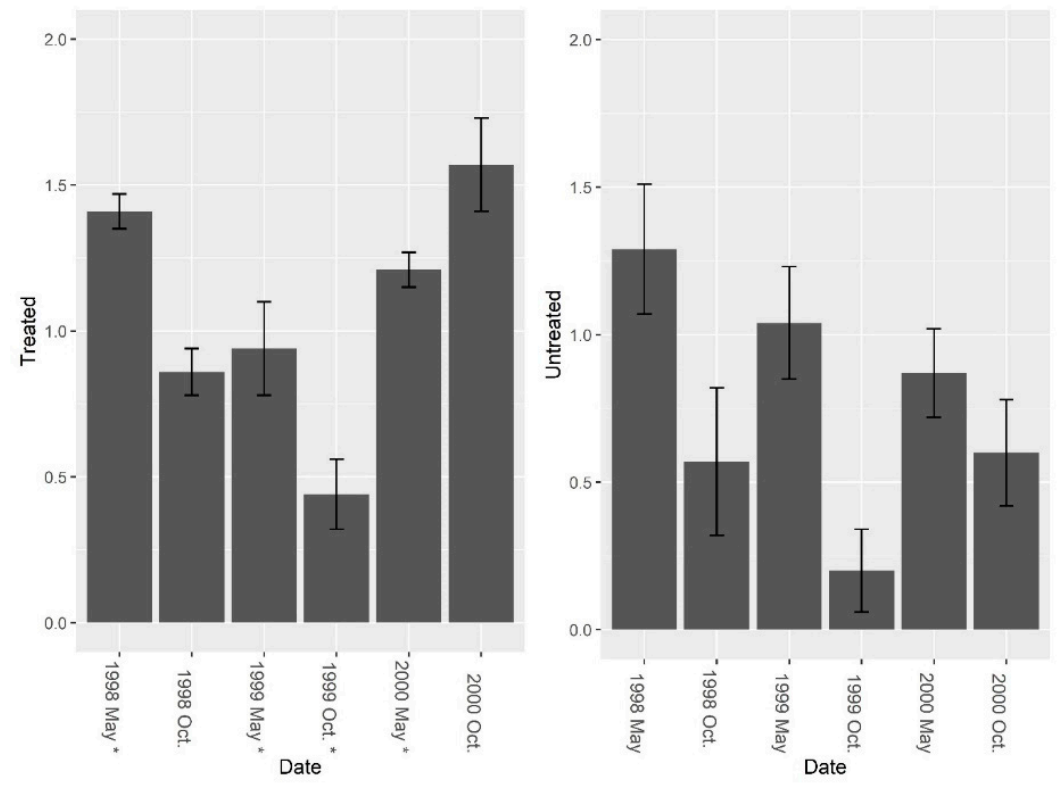

Figure 8. Mean ( $\pm 1 \mathrm{SE}$ ) Shannon diversity indices (excluding fire ants) collected from burrow vacuuming at five pairs of treated and untreated study sites at CSJFTC, 1998-2000. Pre-treatment species diversity (excluding fire ants) was not significantly different between sites $(\mathrm{F}=0.44, \mathrm{df}=4$, $\mathrm{P}=0.543)$, but a post-treatment effect was observed $\left(\mathrm{F}_{1,7}=9.31, \mathrm{P}=0.019\right)$ between treated and untreated sites. Asterisks on the x-axis indicate when treatments occurred.

\section{Discussion}

Repeated treatments with $\mathrm{LOGIC}^{\circledR}$ reduced fire ant abundance in gopher tortoise burrows. Reductions in fire ant abundance resulted in increased species richness and diversity of burrow arthropods sampled with burrow vacuums on treated sites. We did not, however, observe similar results using MSAA in the burrows for ant species. Ant species diversity and richness did not differ between treated and untreated sites. Sampling with baits may not 
provide a representative sample of the ant community as fire ants rapidly recruit to the bait and may exclude other species. After four treatments, differences in invertebrate abundance in vacuum samples became more pronounced and an overall treatment effect was observed. A small number of species influenced analysis of abundance data, particularly Hercostomas sp., which were particularly abundant during the pre-treatment sampling period. When they were removed from the analysis the treatment effect became more pronounced.

The two most abundant invertebrates collected were Eutrichota gopheri and Ceutophilus divergens. Ceutophilis divergens was the most common invertebrate encountered (excluding fire ants). Ceutophilis divergens is a wingless cave or camel cricket and was the second most abundant species encountered in previous surveys [16]; however, the author considered this species an opportunistic inhabitant of the burrow. Eutrichota gopheri is a small, copraphagous fly that feeds on tortoise dung found within the burrow [35]. It was previously known as Pegomyia gopheri, the gopher fly, and was considered an obligate species in gopher tortoise burrows [36]. Eutrichota gopheri was previously the most abundant commensal encountered in surveys of burrow invertebrates in Mississippi [16]. Although it was not the most abundant invertebrate commensal encountered in this study, we recorded it more than $50 \%$ of the time and it was most numerous during spring sampling periods.

After treatments, burrow invertebrate species diversity and richness positively responded on treated sites. There was an absence of the Lepidoptera and Blattaria orders on untreated sites. This may be partly because fire ants are known predators during multiple lepidopteran life stages, including on monarch butterfly larvae (Danaus plexippus) [37], and were suggested as a driving factor preceding a $50 \%$ decline in lepidopteran abundance in Texas post-invasion [38]. Research suggests that fire ants may also be a factor in the decline of the federally endangered Schaus swallowtail butterfly (Papilio aristodemus ponceanus) in the Florida Keys [39], and in laboratory experiments with a surrogate swallowtail species researchers documented predation on all immature life stages.

The introduction and spread of fire ants into the upland habitats of the gopher tortoise has the potential to negatively impact a highly diverse commensal invertebrate community. Fire ants may be able to change the burrow invertebrate community through interspecific competition, either exploitative (when fire ants using resources deprives other species of resources) or interference (when a species is harmed by direct fire ant interactions, including predation) [40].

Regardless of the mechanism, the presence of fire ants may result in changes to the larger burrow ecosystem. This may result in changes to the larger burrow ecosystem. Although not investigated in this study, many species that inhabit the burrow system are copraphagous and act as decomposers of tortoise dung found at the terminus of the burrow. If fire ants reduce the diversity and abundance of copraphagous insects, dung may accumulate in burrow systems. In addition, species that feed on copraphagous insects may be negatively impacted, resulting in a cascade of impacts to other burrow invertebrates and ultimately the entire burrow system. The invertebrate burrow community provides increased prey for insectivorous species including other insects and birds [41,42].

However, this evidence suggests that the same characteristics that make gopher tortoise burrows attractive to fire ants also create opportunities for more effective control of fire ants, and thus conservation of the greater burrow system. Repeated LOGIC ${ }^{\circledR}$ applications significantly reduced the abundance of fire ants in both the burrow bait and vacuum sampling, which was followed by a significant increase in overall insect abundance and diversity in the burrow vacuum samples. This suggests that targeted use of similar pesticide applications may be an effective use of limited conservation and management resources. Since fire ants are generalist predators, fire ant control targeted around gopher tortoise burrows could benefit both the diverse insect species within the burrow, as well as the gopher tortoises themselves, as fire ants have depredated nests and killed hatchlings [19]. This might make eradication of fire ants through bait treatments more effective if treatments are timed after imported fire ants are attracted to the nest, but before hatchlings emerge. Given that gopher tortoise burrows in our study area tend to occur in 
high density colonies [43], and are considered ecosystem engineers that create cascades of processes leading to high local biodiversity [8], this study aligns with others in suggesting the potential of focusing limited conservation resources on biodiversity hotspots $[6,7,44]$.

Supplementary Materials: Supplementary materials are available online at https://www.mdpi. com/1424-2818/13/1/7/s1.

Author Contributions: Conceptualization, D.M.E. and C.R.A.; methodology, D.M.E. and C.R.A.; software, D.M.E. and K.F.E.H.; formal analysis, D.M.E.; investigation, D.M.E.; resources, D.M.E.; writing—original draft preparation, D.M.E.; writing—review and editing, D.M.E. and K.F.E.H.; supervision, C.R.A.; project administration, D.M.E.; funding acquisition, D.M.E. All authors have read and agreed to the published version of the manuscript.

Funding: This research was funded by the U.S. Department of Defense, Mississippi Army National Guard in the form of salary support for D.M.E. Salary support for K.F.E. Hogan was provided by the National Science Foundation NRT-INFEWS: Training in Theory and Application of Cross-scale Resilience in Agriculturally Dominated Social Ecological Systems, Grant No. DGE-1735362. Any opinions, findings, and conclusions or recommendations expressed in this material are those of the author(s) and do not necessarily reflect the views of the National Science Foundation. Any use of trade, firm, or product names is for descriptive purposes only and does not imply endorsement by the U.S. Government.

Institutional Review Board Statement: Not applicable.

Informed Consent Statement: Not applicable.

Data Availability Statement: The data presented in this study are available in the Supplementary Materials.

Acknowledgments: This manuscript was improved by comments from A-M Callcott and L. Yager. We also thank two anonymous reviewers for their feedback.

Conflicts of Interest: The authors declare no conflict of interest.

\section{Appendix A}

Table A1. UTM coordinates of all study sites at Camp Shelby Joint Forces Training Center, Mississippi, USA.

\begin{tabular}{ccc}
\hline Site & Northing & Easting \\
\hline Deep Creek Site 1 & 3423586 & 315624 \\
Deep Creek Site 2 & 3423153 & 315479 \\
Training Area 44 Site 1 & 3440128 & 296754 \\
Training Area 44 Site 2 & 3438659 & 296666 \\
Training Area 44 Site 3 & 3440288 & 299548 \\
Training Area 44 Site 4 & 3439513 & 299489 \\
Firing Point 68 & 3449013 & 301776 \\
Firing Point 72 & 3444891 & 303116 \\
Firing Point 121 & 3452081 & 298644 \\
Firing Point 140 & 3451485 & 300308 \\
\hline
\end{tabular}

\section{References}

1. Wilson, E.O. (Ed.) Biodiversity; The National Academies Press: Washington, DC, USA, 1988.

2. Porter, S.D.; Savignano, D.A. Invasion of Polygyne Fire Ants Decimates Native Ants and Disrupts Arthropod Community. Ecology 1990, 71, 2095-2106. [CrossRef]

3. Dirzo, R.; Young, H.S.; Galetti, M.; Ceballos, G.; Isaac, N.J.B.; Collen, B. Defaunation in the Anthropocene. Science 2014, 345, 401-406. [CrossRef] [PubMed]

4. Hallmann, C.A.; Sorg, M.; Jongejans, E.; Siepel, H.; Hofland, N.; Schwan, H.; Stenmans, W.; Müller, A.; Sumser, H.; Hörren, T.; et al. More than 75 percent decline over 27 years in total flying insect biomass in protected areas. PLoS ONE 2017, 12, e0185809. [CrossRef] [PubMed] 
5. $\quad$ Banks-Leite, C.; Pardini, R.; Tambosi, L.R.; Pearse, W.D.; Bueno, A.A.; Bruscagin, R.T.; Condez, T.H.; Dixo, M.; Igari, A.T.; Martensen, A.C.; et al. Using ecological thresholds to evaluate the costs and benefits of set-asides in a biodiversity hotspot. Science 2014, 345, 1041-1045. [CrossRef] [PubMed]

6. Poynton, J.C.; Loader, S.P.; Sherratt, E.; Clarke, B.T. Biodiversity hotspots for conservation priorities. Biodivers. Conserv. 2007, 16, 853-858. [CrossRef]

7. Roberts, C.M.; McClean, C.J.; Veron, J.E.N.; Hawkins, J.P.; Allen, G.R.; McAllister, D.E.; Mittermeier, C.G.; Schueler, F.W.; Spalding, M.; Wells, F.; et al. Marine biodiversity hotspots and conservation priorities for tropical reefs. Science 2002, 295, 1280-1284. [CrossRef]

8. Kinlaw, A.; Grasmueck, M. Evidence for and geomorphologic consequences of a reptilian ecosystem engineer: The burrowing cascade initiated by the Gopher Tortoise. Geomorphology 2012, 157-158, 108-121. [CrossRef]

9. Alexy, K.J.; Brunjes, K.J.; Gassett, J.W.; Miller, K.V.; Alex, K.J.; Brunjes, K.J.; Gassett, J.W.; Miller, K.V. Continuous Remote Monitoring of Gopher Tortoise Burrow Use. Wildl. Soc. Bull. 2003, 31, 1240-1243.

10. Jackson, D.R.; Milstrey, E.G. The fauna of gopher tortoise burrows. In Proceedings of the Gopher Tortoise Relocation Symposium, Tallahassee, FL, USA; 1989; pp. 86-98.

11. Guyer, C.; Hermann, S.M. Patterns of size and longevity of gopher tortoise (Gopherus polyphemus) burrows: Implications for the longleaf pine ecosystem. Chelonian Conserv. Biol. 1997, 2, 507-513.

12. Milstrey, E.G. Ticks and invertebrate commensals in Gopher Tortoise burrows: Implications and importance. In Proceedings of the 5th Annual. Meeting Gopher Tortoise Council, Gainesville, FL, USA; 1986; pp. 4-15.

13. Pike, D.A.; Mitchell, J.C. Burrow-dwelling ecosystem engineers provide thermal refugia throughout the landscape. Anim. Conserv. 2013, 16, 694-703. [CrossRef]

14. Ennen, J.R.; Kreiser, B.R.; Qualls, C.P. Low Genetic Diversity in Several Gopher Tortoise (Gopherus polyphemus) Populations in the Desoto National Forest, Mississippi. Herpetologica 2010, 66, 31-38. [CrossRef]

15. Clostio, R.W.; Martinez, A.M.; Leblanc, K.E.; Anthony, N.M. Population genetic structure of a threatened tortoise across the south-eastern United States: Implications for conservation management. Anim. Conserv. 2012, 15, 613-625. [CrossRef]

16. Lago, P.K. A survey of arthropods associated with Gopher Tortoise burrows in Mississippi. Entomol. News 1991, $102,1-13$.

17. Callcott, A.-M.A.; Collins, H.L. Invasion and Range Expansion of Imported Fire Ants (Hymenoptera: Formicidae) in North America from 1918-1995. Florida Entomol. 1996, 79, 240-251. [CrossRef]

18. The University of Georgia EDDMapS: Red Imported Fire Ant Solenopsis Invicta (Buren). Available online: https://www.eddmaps. org/distribution/viewmap.cfm?sub=4675 (accessed on 23 November 2020).

19. Epperson, D.M.; Heise, C.D. Nesting and hatchling ecology of Gopher Tortoises (Gopherus polyphemus) in southern Mississippi. J. Herpetol. 2003, 37, 315-324. [CrossRef]

20. Jusino-Atresino, R.; Phillips, S.A. Impact of Red Imported Fire Ants on the Ant Fauna of Texas; Westview Press: Boulder, CO, USA, 1994.

21. Morris, J.R.; Steigman, K.L. Southwestern Association of Naturalists Effects of Polygyne Fire Ant Invasion on Native Ants of a Blackland Prairie in Texas. Southwest. Nat. 1993, 38, 136-140. [CrossRef]

22. Epperson, D.M.; Allen, C.R. Red Imported Fire Ant Impacts on Upland Arthropods in Southern Mississippi. Am. Midl. Nat. 2010, 163, 54-63. [CrossRef]

23. Kenis, M.; Auger-Rozenberg, M.A.; Roques, A.; Timms, L.; Péré, C.; Cock, M.J.W.; Settele, J.; Augustin, S.; Lopez-Vaamonde, C. Ecological effects of invasive alien insects. Biol. Invasions 2009, 11, 21-45. [CrossRef]

24. Holway, D.A.; Lach, L.; Suarez, A.V.; Tsutsui, N.D.; Case, T.J. The causes and consequences of ant invasions. Annu. Rev. Ecol. Syst. 2002, 33, 181-233. [CrossRef]

25. Boivin, N.L.; Zeder, M.A.; Fuller, D.Q.; Crowther, A.; Larson, G.; Erlandson, J.M.; Denhami, T.; Petraglia, M.D. Ecological consequences of human niche construction: Examining long-term anthropogenic shaping of global species distributions. Proc. Natl. Acad. Sci. USA 2016, 113, 6388-6396. [CrossRef]

26. Mack, R.N.; Simberloff, D.; Lonsdale, W.M.; Evans, H.; Clout, M.; Bazzaz, F.A. Biotic Invasions: Causes, Epidemiology, Global Consequences, and Control. Ecol. Appl. 2000, 10, 689-710. [CrossRef]

27. Dziadzio, M.C.; Long, A.K.; Smith, L.L.; Chandler, R.B.; Castleberry, S.B. Presence of the red imported fire ant at gopher tortoise nests. Wildl. Soc. Bull. 2016, 40, 202-206. [CrossRef]

28. Jennings, R.; Fritts, T. The Status of the Gopher Tortoise, Gopherus polyphemus Daudin; Unpublished Final Report; United States Fish and Wildlife Service: Jackson, MS, USA, 1983.

29. Wetterer, J.K.; Moore, J.A. Red Imported Fire Ants (Hymenoptera: Formicidae) At Gopher Tortoise (Testudines: Testudinidae) Burrows. Fla. Entomol. 2005, 88, 349-354. [CrossRef]

30. Allen, C.R.; Epperson, D.M.; Garmestani, A.S. Red Imported Fire Ant Impacts on Wildlife: A Decade of Research. Am. Midl. Nat. 2004, 152, 88-103. [CrossRef]

31. Stoker, R.L.; Grant, W.E.; Vinson, S.B. Solenopsis invicta (Hymenoptera: Formicidae) effect on invertebrate decomposers of carrion in central Texas. Environ. Entomol. 1995, 24, 817-822. [CrossRef]

32. Vinson, S.B. Impact of the invasion of the imported fire ant. Insect Sci. 2013, 20, 439-455. [CrossRef]

33. Wojcik, D.P.; Allen, C.R.; Brenner, R.J.; Forys, E.A.; Jouvenaz, D.P.; Lutz, R.S. Red Imported Fire Ants: Impact on Biodiversity. Am. Entomol. 2001, 47, 16-23. [CrossRef]

34. Magurran, A.E. Ecological Diversity and Its Measurement; Princeton University Press: Princeton, NJ, USA, 1988. 
35. Hubbard, H.G. Additional Notes on the insect guests of the Florida land tortoise. Proc. Entomol. Soc. Wash. 1896, 3, $299-302$.

36. Cox, J.; Inkley, D.; Kautz, R. Ecology and Protection needs of Gopher Tortoise (Gopherus polyphemus) Populations Found on Lands Slated for Large-Scale Development in Florida; Nongame Wildlife Program Technical Report No. 4; Florida Game and Fresh Water Fish Commission: Tallahassee, FL, USA, 1987.

37. Calvert, W.H. Fire ant predation on monarch larvae (Nymphalidae: Danainae) in a central Texas prairie. J. Lepid. Soc. 1996, 50, 149-151.

38. Calvert, W.H. Patterns in the spatial and temporal use of the Texas milkweeds (Asclepiadaceae) by the monarch butterfly (Danus plexippus L.) during fall, 1996. J. Lepid. Soc. 1999, 53, 37-44.

39. Forys, E.A.; Quistorff, A.; Allen, C.R. Potential Fire Ant (Hymenoptera: Formicidae) Impact on the Endangered Schaus Swallowtail. Fla. Entomol. 2001, 84, 254-258. [CrossRef]

40. Morrison, L.W. Long-term impacts of an arthropod-community invasion by the imported fire ant, Solenopsis invicta. Ecology 2002, 83, 2337-2345. [CrossRef]

41. Dziadzio, M.C.; Smith, L.L. Vertebrate Use of Gopher Tortoise Burrows and Aprons. Southeast. Nat. 2016, 15, 586-594. [CrossRef]

42. White, K.N.; Tuberville, T.D. Birds and Burrows: Avifauna Use and Visitation of Burrows of Gopher Tortoises at Two Military Sites in the Florida Panhandle. Wilson J. Ornithol. 2017, 129, 792-803. [CrossRef]

43. Richter, S.C.; Jackson, J.A.; Hinderliter, M.; Epperson, D.; Theodorakis, C.W.; Adams, S.M. Conservation genetics of the largest cluster of federally threatened gopher tortoise (gopherus polyphemus) colonies with implications for species management. Herpetologica 2011, 67, 406-419. [CrossRef]

44. Collins, C.D.; Banks-Leite, C.; Brudvig, L.A.; Foster, B.L.; Cook, W.M.; Damschen, E.I.; Andrade, A.; Austin, M.; Camargo, J.L.; Driscoll, D.A.; et al. Fragmentation affects plant community composition over time. Ecography 2017, 40, 119-130. [CrossRef] 